УДК 378.1:004(477)

Воронкін Олексій Сергійович

викладач предметно-циклової комісії загальноосвітніх та соціально-економічних дисциплін, спеціаліст вищої кваліфікаційної категорії, кандидат педагогічних наук

К3 «Сєвєродонецьке обласне музичне училище ім. С. С. Прокоф'єва», м. Сєвєродонецьк, Україна alex.voronkin@gmail.com

\title{
ПЕДАГОГІЧНА СУТНІСТЬ ПОНЯТТЯ «СЦЕНАРІЙ ДИСТАНЦІЙНОГО КУРСУ» (НА ПРИКЛАДІ АВТОРСЬКОГО ДОСВІДУ В ГАЛУЗІ ЕЛЕКТРОНІКИ)
}

\begin{abstract}
Анотація. У статті представлено узагальнені підходи до тлумачення поняття «сценарій дистанційного курсу». Акцентовано увагу на мотивуючих чинниках, які тісно пов'язані із засобами актуалізації інтересу; проблемними питаннями; технологією організацією колективної співпраці; спланованістю навчального процесу; методикою оцінювання результатів діяльності; системою заохочень та ін. Проаналізована розробка сценарію на прикладі авторського дистанційного курсу «Схемотехніка», спрямованого на студентів вищих навчальних закладів, які навчаються за напрямом «Мікро- та наноелектроніка». Розглянуто структуру розділів, передмову, інструкції до курсу, план пропонованої діяльності, цілі навчання, організацію роботи у малих групах, рейтингову оцінку діяльності, а також особливості проведення тематичних форумів-дискусій та рефлексію. Наведено універсальну план-схему з розробки сценарію дистанційного курсу.
\end{abstract}

Ключові слова: вища освіта; дистанційний курс; сценарій; мотивуючі чинники.

\section{1. ВСТУП}

Актуальність і постановка проблеми. Нині тема розробки і вдосконалення дистанційних курсів актуальна як ніколи. На початок 2005 р. згідно протоколу рішення Колегії МОН № 6/2-4 (від 23 червня 2005 р.) вищими навчальними закладами України було задекларовано наявність понад 2200 дистанційних курсів. У 2008 р. їх кількість досягла 4500, разом з тим найбільш використовуваною навчальною платформою було визначено Moodle [1]. Статистичні дані, наведені на сайті Moodle (http://moodle.org/stats, грудень 2016 р.) за всіма країнами світу, свідчать про наявність 74,5 тисяч інсталяцій системи та 11,2 мільйонів дистанційних курсів. Разом 3 тим окремої уваги заслуговують масові відкриті онлайн курси (МООС), у яких за узагальненими оцінками зареєстровано близько 7 млн. студентів у світі з їх загального числа в 100 млн. [2].

Аналіз останніх досліджень і публікацій. Особливості організації дистанційного навчання розглянуто у наукових розвідках багатьох українських дослідників, серед яких [3; 4]: В. Биков, Ю. Богачков, В. Кухаренко, О. Майборода. Питання організації навчання в MOOC-курсах (Massive Open Online Course), LMS-системах (Learning Management System) репрезентовано в працях Н. Болюбаш, К. Бугайчука, О. Глазунової, К. Колос, В. Сергієнка, О. Спіріна та ін. Розробці технологій навчання на основі сценаріїв (scenario-based learning) присвячено роботи багатьох закордонних дослідників, серед яких R. Clark [5], J. Savery [6], D. Dikke [7], L. Juracz [8]. Разом $з$ тим в останні роки як у педагогічній літературі, так й у вітчизняній педагогічній практиці все більшого поширення набуває поняття сценарію дистанційного курсу.

Метою публікації $\epsilon$ спроба на основі аналізу інтерпретацій різних варіантів тлумачень поняття «сценарій курсу» запропонувати власний підхід до його охарактеризування, який би дозволив розкрити актуальні практичні потреби у підготовці та реалізації академічного дистанційного курсу. 


\section{2. МЕТОДИ ДОСЛІДЖЕННЯ}

Під час дослідження були використані теоретичні методи дослідження, а саме: аналіз й узагальнення наукової літератури 3 проблеми дослідження; системний, індуктивний, дедуктивний підходи щодо здійснення аналізу сценарію авторського курсу; інтерпретація результатів дослідження.

\section{3. РЕЗУЛЬТАТИ ДОСЛІДЖЕННЯ}

\section{1. Зміст поняття «сценарій курсу»}

Розглядаючи проблему розробки сценарію дистанційного курсу, автори публікації [9] пропонують звертати увагу на: актуальність змісту, націленість на кінцевій результат, мотивування слухачів (навіщо потрібен курс, що слухач отримає після його завершення), практичну орієнтованість (спрямованість на вивчення матеріалу, що представляє безпосередню практичну значимість або план організації діяльності слухачів на основі теоретичного матеріалу). Дослідники І. Кушнір, І. Петров i Т. Курілюк, розглядаючи особливості, можливості та проблеми дистанційного навчання, виокремлюють у структурі дистанційного курсу такий елемент, як «сценарій курсу», що включає рекомендації для студентів щодо послідовності й часу вивчення матеріалу й умов проведення поточного та підсумкового модульного контролю [10].

Т. Кульман, досліджуючи сценарії курсів, пропонує шаблон, що складається 3 трьох елементів взаємодії [11]: постановка проблеми - вибір - наслідок. Спочатку слухачі мають осмислити зміст, потім - бути готовими приймати рішення на основі наданого вибору, разом із цим кожне рішення має призводити до певних наслідків. табл. 1.

Зміст поняття «сценарій курсу» за визначеннями різних експертів подано у

Таблиия 1

Зміст поняття «сценарій курсу»

\begin{tabular}{|c|c|l|}
\hline № & Рік / Експерт & \multicolumn{1}{c|}{ Смислове значення поняття } \\
\hline 1 & $\begin{array}{c}2002 \\
\text { В. Демкін, } \\
\text { Г. Можаєва }\end{array}$ & $\begin{array}{l}\text { цілеспрямована, особистісно-орієнтована, методично } \\
\text { вибудувана послідовність педагогічних методів і технологій } \\
\text { для досягнення педагогічних цілей і прийомів [12] }\end{array}$ \\
\hline 2 & $\begin{array}{c}2010 \\
\text { Б. Новокрещін }\end{array}$ & $\begin{array}{l}\text { методично вибудувана послідовність педагогічних методів і } \\
\text { технологій для досягнення педагогічних цілей [13] }\end{array}$ \\
\hline $\begin{array}{c}2011 \\
\text { Д. Руткаускьене } \\
\text { Р. Кубілюнас, } \\
\text { Д. Гудоніене }\end{array}$ & $\begin{array}{l}\text { електронний навчальний ресурс, який визначає порядок і } \\
\text { логіку вивчення курсу [14] }\end{array}$ \\
\hline 4 & $\begin{array}{l}\text { структуроване розгорнуте уявлення автора (-ів) про зміст і } \\
\text { структуру навчального матеріалу, про педагогічні та } \\
\text { iнформаційні технології, які використовуються для організації } \\
\text { навчального процесу, про методичні принципи та прийоми, на } \\
\text { яких побудовано як навчальний матеріал, так і систему його } \\
\text { супроводу [15] }\end{array}$ \\
\hline 5 & $\begin{array}{l}\text { повний і детальний текстовий опис того, яким буде майбутній } \\
\text { електронний курс: які графічні і технічні особливості будуть } \\
\text { використані, що буде відбуватися на кожному слайді } \\
\text { інтерактивного курсу тощо [16] }\end{array}$ \\
\hline
\end{tabular}


Підсумовуючи вищесказане, виокремлюючи основні збіжності, визначимо сценарій курсу як детальний план, що встановлює мету і результати навчання, описує способи подання і доставки навчального контенту, методи взаємодії суб'єктів навчального процесу. Сценарій має спиратися на знання і навички, які несе курс [17], психолого-педагогічні концепції навчання, а також включати визначення змісту навчального контенту, описувати співвідношення між його елементами, у тому числі теоретичними, практичними, контрольними та довідковими [18].

\section{2. Підходи у створенні сценарію}

Дослідниками рекомендовано дотримуватися наступних підходів у створенні навчального курсу [19]: виклад матеріалу має бути строго послідовним, порції подачі матеріалу - невеличкими, ілюстративні можливості - доповнюватися інтерактивними технологіями.

Однак, для потенційного слухача інтерес представляє план пропонованої діяльності з урахуванням деталізованих цілей навчання і методика оцінювання цієї діяльності. Саме тому під час створення сценарію доцільно орієнтуватися на UDLпідходи (Universal Design for Learning), особливо у контексті постановки чітких навчально-методичних цілей, структури курсу, методів навчання, плану діяльності слухачів і тьютора, рейтингової системи оцінювання досягнень [20; 21$]$.

Курс, у якому відбуваються навчальні події, спільно конструюється зміст, обговорюються проблемні питання завжди викликає бажання брати у ньому активну участь. Разом з цим важливу роль відіграє вмотивованість слухачів. Загальновідомо, що на зниження мотивації впливають такі чинники:

- подання матеріалу (відсутність оптимізації тексту (шрифт, колір, розмір), поширення сканованих паперових матеріалів і книг тощо);

- монотонність, одноманітність, відсутність динаміки і подій у «житті» курсу;

- біхевіористський підхід у реалізації навчання;

- невідповідність внутрішнім потребам учня з цілями і завданнями курсу;

- несвоєчасне оцінювання тьютором виконаних завдань;

- відсутність потижневого планування навчального процесу;

- перевантаженість (складний курс вимагає багато часу і сил для проходження);

- самоусунення тьютора;

- примушення до навчання в курсі.

Дж. Келлер рекомендує використовувати модель, в основу якої покладено увагу, значимість, впевненість і задоволення [22]. Згідно моделі, спочатку треба привернути увагу учня, потім його потрібно переконати у важливості і значущості навчання, після чого слід підтримувати впевненість у собі [23].

Розробникам курсу необхідно формувати навчальний контент так, щоб по можливості кожен слухач побачив значимість цих матеріалів для себе (зв'язок 3 життям, питання в тексті, чатах, форумах тощо). Тут слід використовувати ергономічні презентації, розсилку подій, наперед ознайомлювати з планом занять, дискусій. Бажано застосовувати підказки, звертати увагу на особистість слухача, оперативно реагувати на запитання i труднощі, хвалити успішних учнів, оговорювати неоднозначні моменти [24]. Такі дії сприяють підвищенню впевненості слабо мотивованих учнів і підтримують більш мотивованих. У той же час між ними буде розвиватися суперництво (змагання). У будь-якому випадку, наприкінці курсу вмотивованість всіх слухачів буде знижуватися (з різних причин), але всі вони мають відчувати задоволеність навчанням.

Отже, під час створення сценарію курсу передусім доцільно звертати увагу на:

- засоби актуалізації інтересу (використання пізнавальних відео, аудіо ресурсів); 
- проблемні питання й обговорення (планування проблемних ситуацій й активізації пізнавально-пошукового інтересу, добір навчального відео, анімацій тощо);

- спільні продукти колективної праці (використання форумів, чатів, семінарів, вікіпедій);

- цілі і завдання курсу (спрямованість на певну аудиторію - вік, освіта, мова та ін.);

- потижневе планування процесу навчання;

- методику оцінки результатів діяльності учнів;

- таксономію Блума як основу категоризації навчальних матеріалів і завдань;

- комплекс заходів із заохочення;

- діяльнісний підхід.

Як приклад узагальнено розглянемо сценарій авторського дистанційного курсу «Схемотехніка», що читався нами для студентів Східноукраїнського національного університету імені Володимира Даля у 2015-2016 роках. Цей курс було доопрацьовано під час навчання за програмою «Практикум тьютора 3 навчальної дисципліни», що проводилося проблемною лабораторією дистанційного навчання Національного технічного університету «Харківський політехнічний інститут» 32 листопада по 15 грудня 2015 p.

\section{3. Сценарій дистанційного курсу «Схемотехніка»}

Дистанційний курс представлено такою структурою розділів: 1) вступний розділ, де розміщена інформація, що відноситься до всього курсу (відомості про тьютора, мета навчання, вимоги до слухачів, експертиза курсу, презентація, інструкції, план діяльності студентів, рейтингова оцінка діяльності, глосарій, теми до реферату, бібліографічні джерела та гіперпосилання, форум знайомств, консультаційний форум, розклад вебінарів); 2) тематичні розділи, що містять навчально-методичні матеріали 3 окремих тем курсу й оціночні заходи.

Відомості про тьютора включають інформацію про посаду, освіту, стаж науковопедагогічної діяльності, наукові інтереси. Додаткові контакти для зв'язку з тьютором поза системою LMS подано у вигляді ментальної карти (рис. 1).

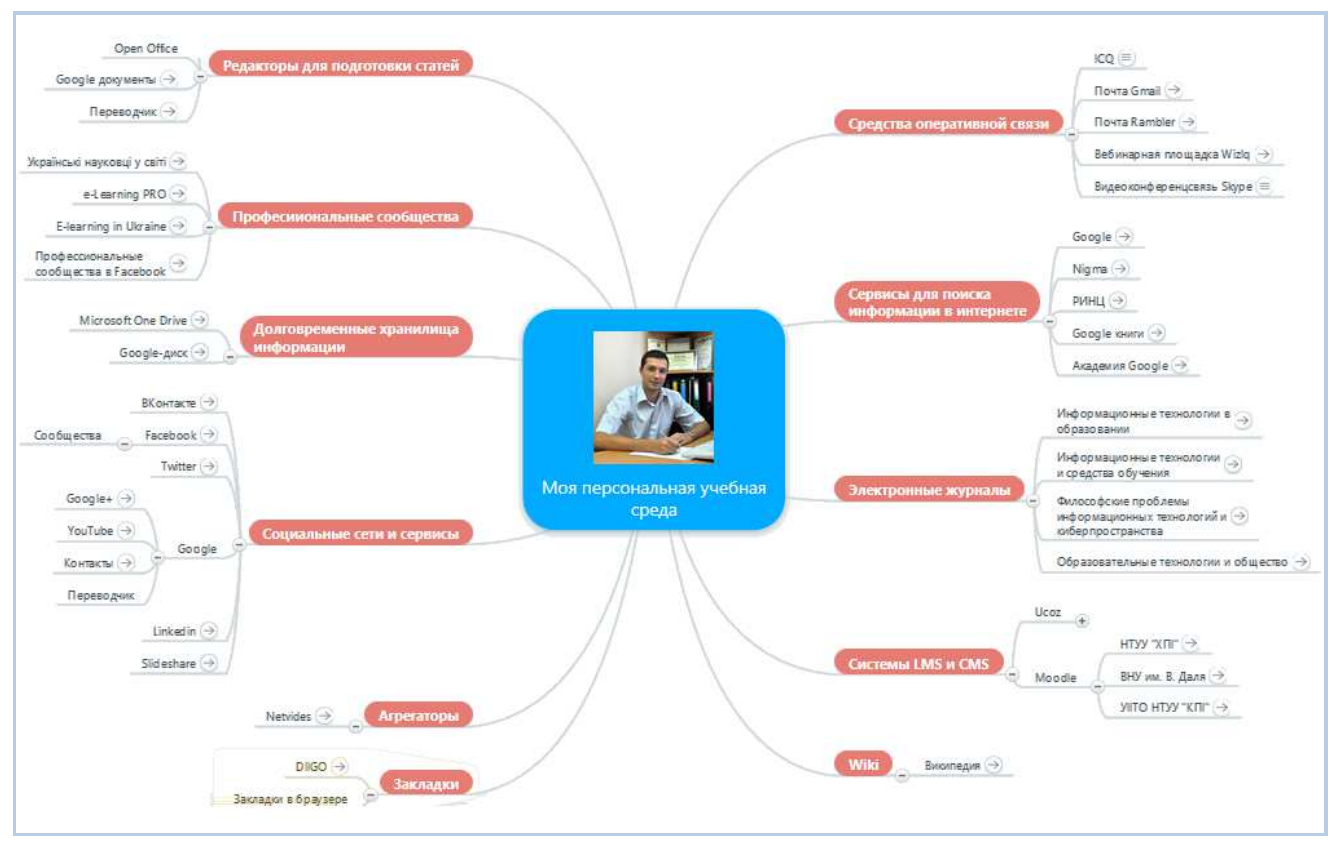

Рис. 1. Персональне середовище тьютора (https://www.mindmeister.com/620329930/2) 


\subsection{1. Приклад передмови до курсу}

У дистанційному курсі 3 мінімальним використанням математичного апарату пропонуються до розгляду схемотехнічні принципи побудови мікроелектронних підсилювачів, що становитиме інтерес для подальшої розробки й проектування електронних систем.

Метою навчання $€$ формування знань у шалузі схемотехніки аналогових підсилювальних пристроїв, що застосовуються в електроніці.

Вимоги до слухачів є такі: курс призначено для студентів, що навчаються за напрямом «Мікро- та наноелектроніка», також буде корисний для студентів бакалавратів, програмою яких передбачено вивчення теорії електричних підсилювачів 3 дисциплін «Електроніка», «Мікросхемотехніка», «Схемотехніка аналогових пристроїв».

Курс відповідає матеріалам електронного засобу навчального призначення «Мікроелектронні підсилювачі» (рис. 2), рекомендованого Міністерством освіти і науки України (Лист № 1/11-126 від 11.01.2011 р.) [25].
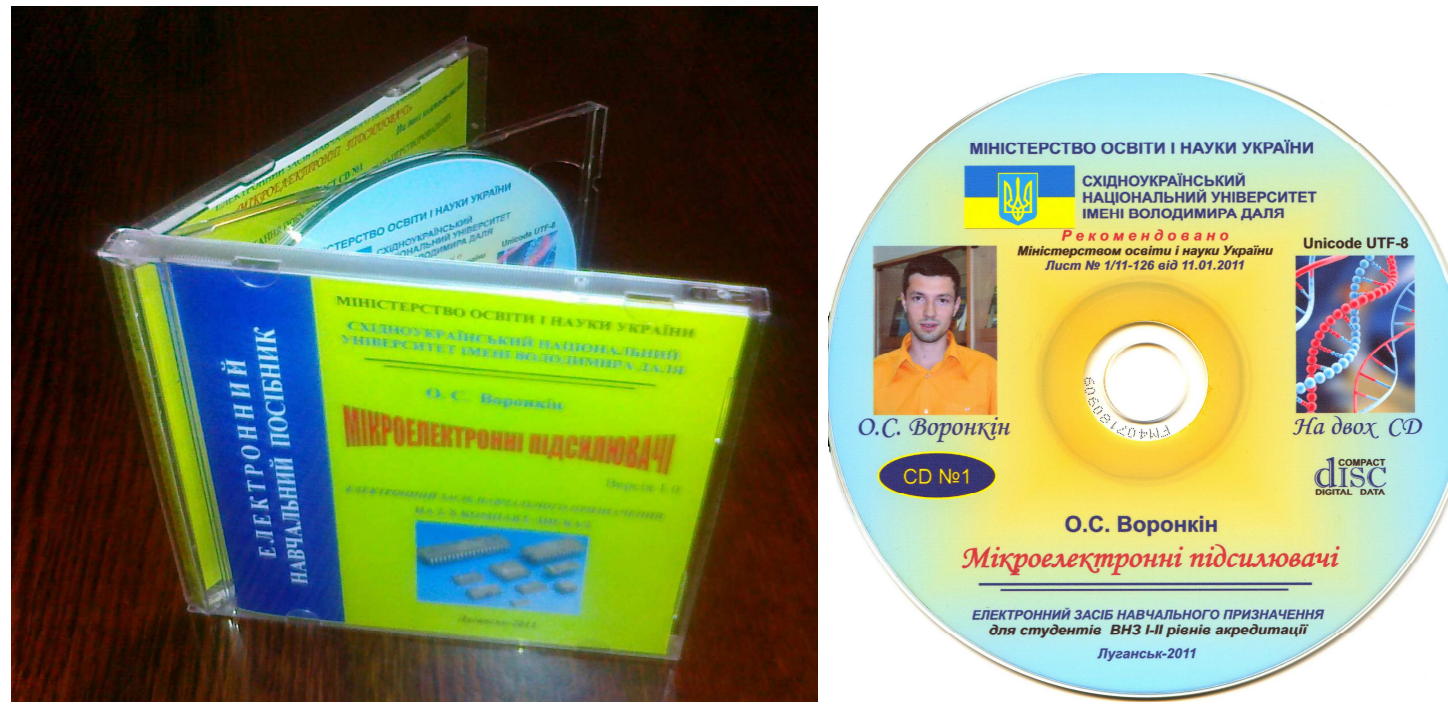

Рис. 2. Електронний засіб навчального призначення «Мікроелектронні підсилювачі» на двох CD-дисках

Для його успішного опанування необхідно мати доступ до Інтернет-мережі, вміти працювати в будь-якому текстовому процесорі, на власному комп'ютері мати встановлену програму Electronic Worckbench, а також мати власну поштову скриньку.

3 презентацією курсу можна ознайомитися за гіперпосиланням http://www.slideshare.net/AlexVoronkin/c-54910786.

Слухачі, які закінчать курс, будуть:

- мати науково-технічний кругозір у галузі схемотехніки аналогових пристроїв, призначених для підсилення й функціонального перетворення електричних сигналів;

- знати принцип дії пристроїв аналогової електроніки; методи розрахунку й проектування підсилювальних каскадів;

- yміти: а) читати електронні схеми; б) виконувати вибір необхідної елементної бази пристроїв аналогової електроніки; в) проводити комп’ютерне моделювання.

Розглянемо інструкції до курсу - загальну, до лабораторних робіт і до дискусій. 


\subsection{2. Приклад інструкцій до курсу}

\section{Загальна інструкиія}

1. Курс проходитиме у системі Moodle (Modular Object-Oriented Dynamic Learning Environment).

2. Розрахований на 17 навчальних тижнів і складається з двох модулів.

3. Вивчення однієї теми відбувається протягом 1 тижня.

4. Перед першим тижнем відкриється доступ до презентації з описом всього курсу.

5. Кожного тижня слухач отримує навчальні елементи для обов'язкового опрацювання (теоретичний матеріал і завдання для виконання).

6. Для підготовки звіту з виконаної роботи слід використовувати текстовий процесор. При цьому обсяг файлу-звіту не повинен перевищувати 1 Мб, в іншому випадку його слід заархівувати. Передача файлів тьютору здійснюється виключно через Moodle.

7. Завдання $з$ лабораторної роботи вважається виконаним, якщо прикріплено 2 файли - текстовий звіт (doc, docx, odt файли) і файл з електронною схемою (у форматі ewb), створений у пакеті схематичного моделювання цифрових, аналогових та аналого-цифрових електронних схем Electronic Workbench.

8. Для обговорення навчального матеріалу рекомендовано використовувати форум.

9. Для спілкування в системі у реальному часі доцільно використовувати чат.

10. Інформаційні (організаційні) повідомлення тьютора дублюватимуться через Google-групу https:/groups.google.com/forum/\#!forum/tu_tor, до якої також бажано приєднатися.

Інструкція до виконання лабораторних робіт

1. Під час проведення лабораторної роботи необхідно користуватися методичними вказівками, наданими до даної роботи і відповідним теоретичним матеріалом.

2. Робота проводиться в середовищі Electronic Worckbench 5.12 або вищої версії.

3. Файл-звіт про виконану роботу повинен мати таку структуру:

3.1) титульний аркуш із зазначенням назви роботи;

3.2) мета роботи;

3.3) опис комп'ютерної моделі або електронної схеми;

3.4) дотримання заданого порядку виконання роботи;

3.5) наведено формули для розрахунку похибок вимірювання (залежно від номера роботи цей пункт може бути відсутнім);

3.6) заповнені таблиці, наведені розрахунки та осцилограми (залежно від номера роботи);

3.7) описані результати, сформульовані висновки;

4. Коли роботу виконано, а звіт підготовлено, обидва файли слід прикріпити як виконане завдання в курсі.

5. Усі завдання необхідно виконувати вчасно (згідно визначеного графіку) - після закінчення встановленого терміну можливість прикріпити звіт буде закрито.

6. Дозволяється виконувати такі завдання випереджаючи.

Інструкиія до дискусій, обговорень на форумах та у чаті

1. Слід дотримуватися тих самих стандартів поведінки, що й у реальному житті, передусім етики спілкування.

2. Намагайтесь висловлювати свої думки чітко й зрозуміло.

3. Поважайте час, можливості й думку інших слухачів. 
4. Допомагайте порадою один одному, якщо це можливо.

5. Використовуйте фахову термінологію.

6. Не втручайтеся в конфлікти й не припускайте їх.

7. Не соромтеся зайвий раз задати запитання тьютору.

8. Не відхиляйтесь від початкової теми обговорення.

\subsection{3. Оріснтовний план діяльності слухачів курсу}

Цілі навчання у дистанційному курсі (за темами) зведено у табл. 2.

\section{Цілі навчання у дистанційному курсі (за темами)}

\begin{tabular}{|c|c|}
\hline Назва теми & Мета \\
\hline \multicolumn{2}{|r|}{ Модуль 1} \\
\hline $\begin{array}{l}\text { Тема 1. Загальні питання } \\
\text { побудови підсилювачів } \\
\text { електричних сигналів }\end{array}$ & $\begin{array}{l}\text { дослідити загальні питаннями побудови підсилювачів } \\
\text { електричних сигналів та отримати практичні навички } \\
\text { зі створення електронних схем, їх моделювання в } \\
\text { середовищі Workbench }\end{array}$ \\
\hline $\begin{array}{l}\text { Тема 2. Найважливіші } \\
\text { показники підсилювачів }\end{array}$ & $\begin{array}{l}\text { дослідити найважливіші показники підсилювачів } \\
\text { електричних сигналів }\end{array}$ \\
\hline $\begin{array}{l}\text { Тема 3. Режими роботи } \\
\text { електронних підсилювачів }\end{array}$ & дослідити роботу схем на операційному підсилювачі \\
\hline $\begin{array}{l}\text { Тема 4. Зворотний зв'язок } \\
\text { у підсилювачах }\end{array}$ & $\begin{array}{l}\text { дослідити вплив паралельного зворотного зв’ язку за } \\
\text { напругою і за струмом на характеристики } \\
\text { підсилювачів }\end{array}$ \\
\hline $\begin{array}{l}\text { Тема 5. Структурні схеми } \\
\text { підсилювачів із зворотним } \\
\text { зв’язком }\end{array}$ & $\begin{array}{l}\text { дослідити вплив негативного зворотного зв’ язку на } \\
\text { характеристики і параметри підсилювачів }\end{array}$ \\
\hline $\begin{array}{l}\text { Тема 6. Стійкість } \\
\text { підсилювача зі зворотним } \\
\text { зв’язком }\end{array}$ & $\begin{array}{l}\text { визначити умови самозбудження підсилювачів та } \\
\text { навчитися проводити перевірку на стійкість } \\
\text { підсилювача із зворотним зв'язком }\end{array}$ \\
\hline $\begin{array}{l}\text { Тема 7. Біполярні } \\
\text { транзистори }\end{array}$ & $\begin{array}{l}\text { дослідити основні характеристики і змоделювати } \\
\text { роботу підсилюючих каскадів з різними схемами } \\
\text { включення транзисторів }\end{array}$ \\
\hline $\begin{array}{l}\text { Тема } 8 . \text { Застосування } \\
\text { транзисторів для } \\
\text { підсилення електричних } \\
\text { сигналів }\end{array}$ & $\begin{array}{l}\text { дослідити вплив режиму роботи транзистора на форму } \\
\text { вихідного сигналу й основні характеристики } \\
\text { підсилювальних каскадів }\end{array}$ \\
\hline $\begin{array}{l}\text { Тема 9. Підготувати } \\
\text { реферат на задану тему }\end{array}$ & $\begin{array}{l}\text { опанувати навички грамотного оформлення роботи } \\
\text { (навчитися формулювати об'єкт, предмет і мету } \\
\text { дослідження відповідно до отриманого завдання; } \\
\text { характеризувати використані методи дослідження; } \\
\text { описувати хід підготовки і проведення роботи; робити } \\
\text { креслення принципових схем, використовуючи } \\
\text { стандарти) та продемонструвати отриманні знання під } \\
\text { час навчання у першому модулі шляхом складання } \\
\text { тесту }\end{array}$ \\
\hline
\end{tabular}




\begin{tabular}{|l|l|}
\hline \multicolumn{2}{|c|}{ Модуль 2} \\
\hline $\begin{array}{l}\text { Тема 10. Операційні } \\
\text { підсилювачі (ОП) }\end{array}$ & $\begin{array}{l}\text { навчитися знімати амплітудно-частотну } \\
\text { характеристику підсилювачів, побудованих на ОП }\end{array}$ \\
\hline $\begin{array}{l}\text { Тема 11. Операційні схеми } \\
\text { на ОП }\end{array}$ & $\begin{array}{l}\text { дослідити ОП у вигляді суматора, диференціатора та } \\
\text { інтегратора }\end{array}$ \\
\hline $\begin{array}{l}\text { Тема 12. Модуляція } \\
\text { сигналів і схеми } \\
\text { модуляторів }\end{array}$ & дослідити різні типи модуляції \\
\hline $\begin{array}{l}\text { Тема 13. Підсилення і } \\
\text { лінеаризація вихідних } \\
\text { сигналів мостових схем }\end{array}$ & $\begin{array}{l}\text { отримати навички в розрахунку мостових схем і схем } \\
\text { лінеаризації }\end{array}$ \\
\hline $\begin{array}{l}\text { Тема 14. Ізольовані } \\
\text { підсилювачі. підсилювачі } \\
\text { із застосуванням методу } \\
\text { модуляції-демодуляції }\end{array}$ & $\begin{array}{l}\text { оптимізувати схеми модуляції сигналу засобами } \\
\text { комп'ютерного моделювання }\end{array}$ \\
\hline $\begin{array}{l}\text { Тема 15. Підсилювачі, } \\
\text { стабілізовані перериванням }\end{array}$ & $\begin{array}{l}\text { дослідити принцип роботи підсилювачів з } \\
\text { перериваноням) }\end{array}$ \\
\hline $\begin{array}{l}\text { Тема 16. Імпульсні } \\
\text { підсилювачі }\end{array}$ & $\begin{array}{l}\text { придбати практичні навички в розрахунку } \\
\text { підсилювальних каскадів на прикладі вирішення } \\
\text { конкретного завдання }\end{array}$ \\
\hline $\begin{array}{l}\text { Тема 17. Вибірні } \\
\text { (селективні) підсилювачі }\end{array}$ & розглянути принципи роботи селективних контурів \\
\hline $\begin{array}{l}\text { Іспит } \\
\text { скласти іспит за матеріалом всього курсу; } \\
\text { провести самооцінку знань }\end{array}$ \\
\hline
\end{tabular}

Кожен слухач повинен розуміти, який він має набір дій і як кожне 3 них оцінюється, в іншому випадку слухач не виконуватиме жодних дій. Ми дотримуємося технології планування програми курсу за тижнями. Розглянемо узагальнено потижневий план діяльності слухачів курсу.

\section{1-й тиждень}

$\checkmark$ Теорія. Загальні питання побудови підсилювачів електричних сигналів.

$\checkmark$ Лабораторна робота. Знайомство з пакетом схематичного моделювання електронних схем Electronic Workbench.

$\checkmark$ Звіт про виконання роботи.

\section{2-й тиждень}

$\checkmark$ Теорія. Найважливіші показники підсилювачів.

$\checkmark$ Лабораторна робота. Дослідження рівня зміщення вихідної напруги та впливу дестабілізуючих факторів у схемах на операційному підсилювачі.

$\checkmark$ Звіт про виконання роботи.

3-й тиждень

$\checkmark$ Теорія. Режими роботи електронних підсилювачів.

$\checkmark$ Лабораторна робота. Дослідження роботи інтеграторів та диференціаторів, побудованих на операційному підсилювачі.

$\checkmark$ Звіт про виконання роботи.

4-й тиждень

$\checkmark$ Теорія. Зворотний зв'язок в підсилювачах.

$\checkmark$ Тематичний чат.

$\checkmark$ Звіт про виконання роботи. 
5-й тиждень

$\checkmark$ Теорія. Структурні схеми підсилювачів із зворотним зв'язком.

$\checkmark$ Тематичний чат.

$\checkmark$ Тижневий звіт.

6-й тиждень

$\checkmark$ Теорія. Стійкість підсилювача зі зворотним зв'язком.

$\checkmark$ Тематичний чат.

$\checkmark$ Тижневий звіт.

7-й тиждень

$\checkmark$ Теорія. Біполярні транзистори.

$\checkmark$ Історична довідка «Винахід транзистора».

$\checkmark$ Форум-дискусія «Як підсилює транзистор?».

$\checkmark$ Лабораторна робота. Схеми включення транзисторів у підсилюючих каскадах.

$\checkmark$ Звіт про виконання роботи.

8-й тиждень

$\checkmark$ Теорія. Застосування транзисторів для підсилення електричних сигналів.

$\checkmark$ Відео-фрагмент «Транзистор - це дуже просто».

$\checkmark$ Лабораторна робота. Режими роботи транзисторів у підсилюючих каскадах.

$\checkmark$ Звіт про виконання роботи.

9-й тиждень

$\checkmark$ Реферат на задану тему.

$\checkmark$ Контрольні запитання до першого модуля. Виконання тестових завдань.

$\checkmark$ Звіт-рефлексія (за підсумками першого модуля).

10-й тиждень

$\checkmark$ Теорія. Операційні підсилювачі.

$\checkmark$ Історична довідка «Винахід операційного підсилювача».

$\checkmark$ Лабораторна робота. Дослідження амплітудно-частотної характеристики підсилювачів, побудованих на операційному підсилювачі».

$\checkmark$ Робота у малих групах.

$\checkmark$ Звіт про виконання роботи.

11-й тиждень

$\checkmark$ Теорія. Операційні схеми на операційних підсилювачах.

$\checkmark$ Лабораторна робота. Дослідження операційного підсилювача у схемах суматора, диференціатора та інтегратора.

$\checkmark$ Звіт про виконання роботи.

12-й тиждень

$\checkmark$ Теорія. Модуляція сигналів і схеми модуляторів.

$\checkmark$ Лабораторна робота. Дослідження схем амплітудних модуляторів.

$\checkmark$ Звіт про виконання роботи.

13-й тиждень

$\checkmark$ Теорія. Підсилення і лінеаризація вихідних сигналів мостових схем.

$\checkmark$ Лабораторна робота. Дослідження мостових схем на операційному підсилювачі.

$\checkmark$ Звіт про виконання роботи.

14-й тиждень

$\checkmark$ Теорія. Ізольовані підсилювачі. підсилювачі із застосуванням методу модуляції-демодуляції.

$\checkmark$ Лабораторна робота. Дослідження схем амплітудних демодуляторів.

$\checkmark$ Звіт про виконання роботи. 
15-й тиждень

$\checkmark$ Теорія. Підсилювачі, стабілізовані перериванням.

$\checkmark$ Лабораторна робота. Вивчення методів автопідстроювання нуля.

$\checkmark$ Звіт про виконання роботи.

16-й тиждень

$\checkmark$ Теорія. Імпульсні та вибірні підсилювачі.

$\checkmark$ Лабораторна робота. Вивчення властивостей послідовного і паралельного коливальних LC-контурів у схемах підсилювачів.

$\checkmark$ Звіт про виконання роботи.

17-й тиждень

$\checkmark$ Підсумковий чат.

$\checkmark$ Контрольні запитання до другого модуля.

$\checkmark$ Іспит.

$\checkmark$ Звіт-рефлексія.

\subsection{4. Робота в малих групах}

3 метою організації роботи малих груп на 10-му тижні навчання слухачам на вибір пропонуються дві проблеми - пошук несправностей у попередньому підсилювачі та пошук неполадок у кінцевих підсилювачах. Мета: набуття практичних навичок із діагностування неполадок у роботі підсилювачів. Конкретизуємо їх.

Перша проблема - пошук неполадок у попередньому підсилювачі. Друга - пошук неполадок у кінцевих підсилювачах (на прикладі двотактного вихідного каскаду на комплементарних транзисторах $n-p-n$ та $p$ - $n-p)$. Кожен слухач має обрати першу або другу проблему, разом з цим утворивши дві команди (у нашому випадку по 4-5 слухачів). Далі всі вони готуються до командної взаємодії й обмірковують варіанти вирішення поставлених завдань за узагальненим планом:

1. Яке обладнання й інструменти нам знадобляться для діагностики неполадок?

2. Шляхом аналізу літератури, блогів, власного досвіду конкретизувати найбільш поширені типи неполадок даного типу підсилювача.

3. Розробити (запропонувати) загальну методику діагностування та усунення поломок.

Ми пропонуємо таку тематику, у якій слухачі зможуть розглядати себе у ролі експертів. На вебінарі учасники в чаті обговорюють визначене тьютором завдання в межах проблеми й обирають слухача, який даватиме підсумкову відповідь від команди (в аудіо-, відео-режимі). Учасники не мають багато часу, щоб повною мірою узгодити відповідь, у них немає часу на пошуки в Інтернеті або інших джерелах, завдяки цьому тьютору легко відстежити хід колективного спілкування та спільного пошуку, роблячи тим самим висновки про підготовленість усіх учасників команди. Як приклад розглянемо орієнтовний план-сценарій командної взаємодії за першою проблемою.

1. Перед нами ланцюжок підсилювальних попередніх каскадів, на виході якого відсутній сигнал. 3 чого потрібно почати? Яке обладнання нам знадобиться?

Відповідь: Нам знадобиться генератор гармонійного сигналу, осцилограф, мультиметр. На вхід підсилювача подається сигнал, наявність якого послідовно перевіряється після кожного каскаду.

2. Припустимо, ми знайшли несправний каскад, що слід робити далі?

Відповідь: Потрібно виміряти напругу в статичних робочих точках (наприклад, напругу колектор-емітер і напругу база-емітер). Так можемо локалізувати несправний елемент. 
3.1. Повертаємося до пункту 1 , перед нами стоїть наступне завдання. На виході спад підсилення. Часто це відбувається через деякі паразитні параметри електролітичних конденсаторів (наприклад, струм витоку). Як локалізувати проблему?

Відповідь: необхідно визначити підсилення кожного каскаду. Для цього вимірюється змінна напруга перед кожним каскадом і після нього, потім обчислюється коефіцієнт підсилення.

3.2. У даному випадку зручно використовувати двоканальний осцилограф. Чому? виході.

Відповідь: необхідно порівнювати положення фаз і форму сигналу на вході i

4. Припустимо, що у попередньому підсилювачі ми виявили автоколивання. 3 чим це може бути пов'язано?

Відповідь: автоколивання можуть бути викликані неправильно розрахованим негативним зворотним зв'язком і ємнісним навантаженням на виході.

5. Як впливає ємнісне навантаження на виникнення автоколивань?

Відповідь: Смнісне навантаження впливає на швидкість підвищення або зниження напруги на виході. Це обмеження швидкості наростання вихідної напруги призводить до формування фактично трикутної напруги на виході i може привести до нестабільності. Обмеження швидкості наростання вихідної напруги може зустрічатися і в операційному підсилювачі, якщо не враховуються параметри додаткових елементів, рекомендованих виробником для під’єднання до підсилювача, а також у випадку коли не береться до уваги його частотна характеристика і підсилення.

У даному прикладі ми показали використання таких методів, як словесний, проблемно-пошуковий, індуктивний і дедуктивний, таких форм як пошук інформації, аналіз проблемних навчальних ситуацій, зіставлення відповідей, бесіда, побудова гіпотези на основі аналізу наявних даних.

Робота у малих групах дозволяє слухачам отримати емоційну і змістовну підтримку, підтримувати ефект співпраці. У той же час в організації такої роботи слід враховувати особистісні характеристики слухачів, міру розвитку їх дій і предметних умінь, міру зацікавленості.

\subsection{5. Рейтингова оцінка діяльності}

У даному курсі кожне виконане завдання оцінюється максимальною оцінкою 100 балів (у підсумку система MOODLE розраховує середнє арифметичне). Звертаємо увагу, що у системі MOODLE можемо використовувати різні варіанти підведення результатів (зважене значення оцінок, просто-зважене значення, нижча оцінка, найвища оцінка, сума (накопичувальна система оцінювання), мода, медіана). Рейтингова таблиця оцінювання наведена в табл. 3.

Таблиия 3

\section{Рейтингова таблиця оцінювання}

\begin{tabular}{|c|c|c|}
\hline Завдання & $\begin{array}{c}\text { Максимальний } \\
\text { бал }\end{array}$ & \multicolumn{1}{|c|}{ Критерії в балах } \\
\hline $\begin{array}{c}\text { Лабораторна } \\
\text { робота }\end{array}$ & $\begin{array}{l}\text { Акуратність, логічність оформлення звіту }-20 \text { балів } \\
\text { Наявність електричної принципової схеми }-20 \text { балів }\end{array}$ \\
\hline & $\begin{array}{l}\text { Наявність правильних вимірювань (оформлення } \\
\text { результатів у таблиці або в вигляді осцилограм) }-20 \\
\text { балів }\end{array}$ \\
\hline
\end{tabular}




\begin{tabular}{|c|c|c|}
\hline & & $\begin{array}{l}\text { сутність досліджуваного явища із зазначенням } \\
\text { конкретних результатів -20 балів } \\
\text { Наявність файлу з розширенням ewb (файл, створений } \\
\text { програмою моделювання Electronics Workbench) - } 20 \\
\text { балів }\end{array}$ \\
\hline \multirow{5}{*}{ Реферат } & \multirow{5}{*}{100} & Чіткість постановки мети - 20 балів \\
\hline & & Відповідність мети змісту реферату - 20 балів \\
\hline & & Зміст роботи (аналіз схем, режимів тощо) - 20 балів \\
\hline & & $\begin{array}{l}\text { Хід підготовки реферату (розписаний по етапах) - } 20 \\
\text { балів }\end{array}$ \\
\hline & & Наявність висновків - 20 балів \\
\hline \multirow{5}{*}{$\begin{array}{c}\text { Форум- } \\
\text { дискусія, } \\
\text { інформа- } \\
\text { ційний чат, } \\
\text { робота у } \\
\text { малих групах }\end{array}$} & \multirow{5}{*}{100} & Нова ідея - 20 балів \\
\hline & & Порада - 10 балів \\
\hline & & Зауваження - 10 балів \\
\hline & & Пропозиція - 10 балів \\
\hline & & \\
\hline $\begin{array}{c}\text { Тестові } \\
\text { завдання }\end{array}$ & 100 & \\
\hline \multirow{2}{*}{ Іспит } & \multirow{2}{*}{100} & 3 питання по 20 балів кожне \\
\hline & & 1 задача - 40 балів \\
\hline
\end{tabular}

Особливу увагу викликає проведення тематичних форумів-дискусій (або чатів) цей елемент навчання також має ретельно плануватися. Наприклад на 7-му тижні навчання організовується форум «Як підсилює транзистор?». Тут надаються теоретичні відомості й аналогії. Конкретним завданням слухачів $є$ дослідження принципів роботи каскадів RC-типу на біполярному транзисторі (надано електричну схему, чітко окреслено проблемні питання, які потребують вивчення). У цьому форумі кожен слухач дає відповідь у вигляді окремої теми.

В інформаційних чатах пропонуються до колективного обговорення завдання 3 прихованими помилками і роботи, виконані на попередніх етапах самими слухачами 3 помилками.

Пропоновані нами тестові завдання відповідають відсотковому співвідношенню між категоріями відповідно до таксономії Блума в такій пропорції: знання і розуміння (50 \%), використання (25\%), аналіз і синтез (25\%).

\subsection{6. Рефлексія}

Заплановано щотижневе надання звіту, передбачено форум для консультацій i тематичні чати. На 9-му і 17-му тижнях підводяться підсумки, подаються два рефлексивні звіти. Розглянемо їхню структуру.

Перший звіт-рефлексія. Опишіть свої враження щодо проведеної роботи в першому модулі, дотримуючись такої схеми.

1. Чому ви навчилися завдяки теоретичному матеріалу курсу.

2. Перерахуйте навички, набуті під час виконання лабораторних робіт.

3. Що найкраще вдавалося (не вдавалося) під час виконання завдань.

4. Назвіть основні труднощі, які виникали за час навчання.

5. Перерахуйте найбільш ефективні види діяльності, а також дієві способи розв'язання проблем.

6. Які цілі для вас будуть першочерговими під час навчання у другому модулі. 
Другий звіт-рефлексія. Опишіть свої враження щодо навчання у другому модулі зокрема, та у всьому курсі у цілому.

7. Перерахуйте свої основні досягнення.

8. Перерахуйте труднощі, що виникли у вивченні матеріалів курсу.

9. Опишіть, як вдалося подолати виникаючі труднощі.

10. Опишіть зміни, які відбулися у вашій професійній підготовці.

11. Перерахуйте види діяльності у курсі, які вам найбільш сподобалися.

12. Сформулюйте рекомендації щодо поліпшення матеріалів курсу.

13. Що б ви змінили в організації дистанційного курсу, своїй діяльності та діяльності тьютора.

Розгляд авторського досвіду, а також аналіз наукових публікацій [19-24; 26] дозволяє запропонувати універсальну план-схему, що буде корисною під час розробки конкретного сценарію дистанційного курсу (рис. 3).

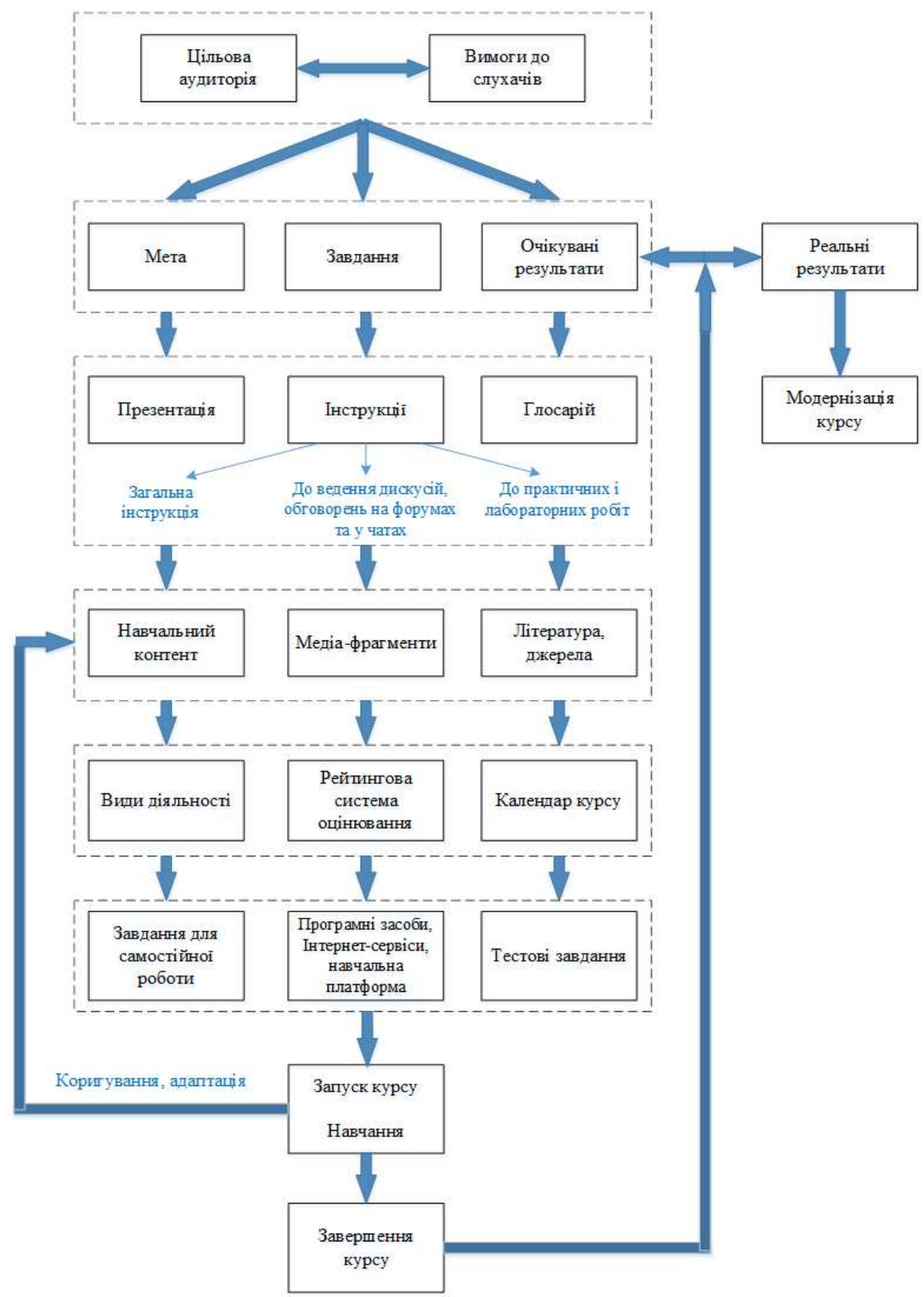

Рис. 3. Узагальнена схема, щ̧о відображає основні етапи розробки дистанційного курсу 
Схема побудована відповідно до найбільш типових етапів [27] розробки дистанційного курсу:

1. Визначення мети i завдань курсу 3 урахуванням цільової аудиторії. Формулювання вимог до слухачів курсу.

2. Визначення результатів навчання, конкретизація компетенцій.

3. Підготовка презентації (відеопрезентації) курсу.

4. Розробка інструкцій:

4.1. загальної (як проходитиме курс, у якій системі дистанційного навчання, які веб-сервіси і програмне забезпечення будуть задіяні додатково і 3 якою метою, терміни навчання, організація самостійної роботи, принципи організації зворотного зв'язку, особливості оцінювання результатів навчання тощо);

4.2. до практичних або лабораторних робіт (програмне середовище, у якому має виконуватися робота, методичні вказівки до роботи у даному середовищі, структура звіту про виконане завдання, існуючі обмеження на обсяг файлів-звітів, термін виконання i термін подання звіту, можливість виконувати завдання випереджаючі);

4.3. до ведення дискусій, обговорень на форумах та у чатах (етика спілкування, стандарти поведінки).

5. Розробка глосарію.

6. Структурування і підготовка навчального контенту (теоретичний матеріал, практичні завдання, тестові завдання, створення форумів). До текстової частини кожної теми рекомендовано включати мету навчання; розміщувати питання у тексті; виокремлювати ключові проблеми за темою; додавати історичні відомості, питання для самоперевірки і рефлексії.

7. Підготовка анімацій і медіафрагментів (відеоряду), розробка рисунків, схем, таблиць.

8. Складання рекомендаційного бібліографічного списку і гіперпосилань на Інтернет-ресурси.

9. Планування видів діяльності, методів взаємодії тьютора і слухачів. Проектування способів закріплення знань і навичок.

10. Розробка рейтингової системи оцінювання діяльності слухачів.

11. Складання календаря курсу.

12. Укладання завдань до самостійної роботи.

13. Наповнення платформи дистанційного навчання.

14. Тестування курсу з використанням різних пристроїв, браузерів.

15. Запуск курсу та його супроводження.

16. Розробка анкет з опитуванням для слухачів, що завершили курс (рефлексія).

\section{3. ВИСНОВКИ ТА ПЕРСПЕКТИВИ ПОДАЛЬШИХ ДОСЛІДЖЕНЬ}

Проведений аналіз найбільш поширених підходів до охарактеризування сценаріїв дистанційних курсів дозволяє зробити такі узагальнюючи висновки:

- на основі аналізу наукових публікацій встановлено, що сценарій дистанційного курсу має відображати кінцевій результат, систему засобів мотивування, практичну орієнтованість, план діяльності тьютора і слухачів, методику оцінювання їхніх досягнень, разом 3 тим поняття сценарію курсу у даний час не можна вважати усталеним;

- під сценарієм курсу у даній роботі ми розуміємо детальний план, що визначає мету і результати навчання, описує способи подання та доставки навчального 
контенту, методи взаємодії суб'єктів навчального процесу, спирається на психолого-педагогічні концепції навчання та визначає співвідношення між теоретичними, практичними, контрольними і довідковими складниками;

- запропоновано універсальну план-схему, що відображає основні етапи розробки дистанційного курсу та стане у нагоді під час розробки конкретного сценарію дистанційного курсу;

- на авторському прикладі показано, що під час створення сценарію курсу доцільно зосередитися на плануванні (проектуванні) змісту, організації системи навчання та оцінюванні. Конкретизуємо деякі базові положення, на які слід звертати увагу розробнику сценарію курсу:

1) сценарій спирається на певні стандарти навчання, незалежно від програмної платформи [28]. В його основу покладено педагогічні принципи, а не тільки програмно-апаратні;

2) описано технологічний варіант організації курсу. Додавання нових програмно-апаратних технологій у дистанційний курс передбачає внесення змін на етапі розробки сценарію;

3) закладено механізми, що забезпечують гостинну атмосферу, розуміння слухачами використовуваних методів i засобів навчання, ефективну співпрацю;

4) цілі навчання конкретні та відкриті. Кожна навчальна мета включає в себе критерії оцінювання [29];

5) завдання відповідають поставленим цілям. Надано певний вибір у постановці цілей і виконанні завдань;

6) у систему оцінювання покладені чітко сформульовані критерії. Критерії включені в систему рейтингового оцінювання й описані в інструкції 3 виконання того чи іншого завдання, у тому числі тестового;

7) передбачено комплекс заходів, спрямованих на мотивацію слухачів;

8) передбачено формати міжособистісної взаємодії (форуми, чати, дискусії, робота у малих групах тощо);

- сформульовані нами положення можуть слугувати основою для подальших досліджень проблем проектування й реалізації сценаріїв дистанційних курсів. Разом з тим ідеї і підходи, розглянуті у контексті охарактеризування проблеми створення сценаріїв, залишаються відкритими для подальших змін і уточнень.

\section{СПИСОК ВИКОРИСТАНИХ ДЖЕРЕЛ}

1. Малюкова И. Г. Применение ИКТ в высшем образовании Украины [Електронний ресурс] / И. Г. Малюкова // Применение ИКТ в высшем образовании стран СНГ и Балтии: текущее состояние, проблемы и перспективы развития : аналитический обзор. - СПб. : ГУАП, 2009. С. 130-153. - Режим доступу : http://iite.unesco.org/pics/publications/ru/files/3214561.pdf. - Назва 3 екрана.

2. Кузьминов Я. И. Фактически мы имеем дело с революцией [Електронний ресурс] / Я. И. Кузьминов // Сайт Высш. шк. экономики. - 2013. - Режим доступу : http://www.hse.ru/news/105336334.html. - Назва з екрана.

3. Богачков Ю. М. Концепція проекту «дистанційне навчання школярів» [Електронний ресурс] / Ю. М. Богачков, В. Ю. Биков, В. О. Красношапка, В. М. Кухаренко, Ю. Я. Пасіхов // Інформаційні технології і засоби навчання. - 2009. - № 5 (13). - Режим доступу : http://journal.iitta.gov.ua/index.php/itlt/article/view/186/172. - Назва з екрана.

4. Майборода О.В.Дистанційне навчання як пріоритетний напрямок вищої освіти / О. В. Майборода // Інфо рмаційні технології і засоби навчання. - 2011. - № 5 (25). -Режим доступу : http://journal.iitta.gov.ua/index.php/itlt/article/view/452/440. - Назва з екрана. 
5. Clark R. Accelerating expertise with scenario based learning [Електронний pecypc] / R. Clark // Learning Blueprint. Merrifield, VA : American Society for Teaching and Development, 2009. - Jan. P. 84-85. - Режим доступу : http://www.clarktraining.com/content/articles/ScenarioBasedLearning.pdf. - Назва $з$ екрана.

6. Savery J. R. Overview of Problem-based Learning: Definitions and Distinctions [Електронний ресурс] / J. R. Savery // Interdisciplinary Journal of Problem-based Learning. - 2006. - № 1 (1). - P. 9-20. Режим доступу : http://docs.lib.purdue.edu/ijpbl/vol1/iss1/3. - Назва з екрана.

7. Dikke D. Go-lab MOOC-an online course for teacher professional development in the field of inquirybased science education [Електронний pecypc] / D. Dikke, N. Faltin. - Режим доступу : http://www.golab-project.eu/sites/default/files/files/publications/file/EDULEARN_MOOC_final.pdf. - Назва $з$ екрана.

8. Juracz L. Developing courses with holorena, a framework for scenario-and game based e-learning environments [Електронний ресурс] / L. Juracz // International Journal of Software Engineering \& Applications (IJSEA). - 2010. - Vol. 1. - № 4. - Режим доступу : https://arxiv.org/ftp/arxiv/papers/1011/1011.0350.pdf. - Назва з екрана.

9. 7 Tips for Better E-Learning Scenarios [Електронний pecypc]. - Режим доступу : http://blogs.articulate.com/rapid-elearning/7-tips-for-better-e-learning-scenarios. - Назва з екрана.

10. Кушнір I. М. Структура дистанційного курсу 3 російської мови для іноземних студентів нефілологічних спеціальностей [Електронний ресурс] / I. М. Кушнір, І. В. Петров, Т. І. Курілюк // Викладання мов у вищих навчальних закладах освіти на сучасному етапі. Міжпредметні зв'язки. Наукові дослідження. Досвід. Пошуки. - 2013. - Вип. 23. - С. 43-53. - Режим доступу : http://www-center.univer.kharkov.ua/vestnik/full/351.pdf. - Назва з екрана.

11. Build Branched E-Learning Scenarios in Three Simple Steps [Електронний ресурс]. - Режим доступу : http://blogs.articulate.com/rapid-elearning/build-branched-e-learning-scenarios-in-three-simple-steps. Назва з екрана.

12. Демкин В. П., Технологии дистанционного обучения / В. П. Демкин, Г. В. Можаева. - Томск : Издво: Том. гос. ун-та, 2003. - 106 с.

13. Новокрещин Б. Г. Сценарии обучения [Електронний ресурс] / Б. Г. Новокрещин. - Режим доступу : http://www.proshkolu.ru/contest/scenarii/blog/51090. - -Назва з екрана.

14. Руткаускьене Д. Технологии и ресурсы электронного обучения / Д. Руткаускьене, Р. Кубилюнас, Д. Гудониене и др. - Харьков : Точка, 2011. - 352 с.

15. Третий внутриуниверситетский конкурс по отбору педагогических сценариев открытых онлайнкурсов [Електронний ресурс]. - Режим доступу : https://ido.tsu.ru/competitions/h_teachers-3/2015-16. - Назва з екрана.

16. Семаш К. Грамотный сценарий электронного курса [Електронний ресурс] / К. Семаш. - Режим доступу : http://y-coach.ru/gramotnyj-scenarij-elektronnogo-kursa. - Назва з екрана.

17. Сценарий электронного курса [Електронний ресурс]. - Режим доступу : https://www.crmm.ru/knowledge_base/Sozdanije_elektronnogo_kursa/Scenarij_elektronnogo_kursa. Назва з екрана.

18. Семенченко Р. Д. Сценарии обучения в обучающих тренажерах [Електронний ресурс] / Р. Д. Семенченко // Наука и современность. - 2016. - № 44. - Режим доступу : http://cyberleninka.ru/article/n/stsenarii-obucheniya-v-obuchayuschih-trenazherah. - Назва з екрана.

19. CourseLab 2.7 Руководство пользователя [Електронний ресурс]. - Режим доступу : http://www.courselab.ru/courselab/WebHelp/indexh.htm. - Назва з екрана.

20. Universal Design for Learning in the Classroom: Practical Applications / edited by T. E. Hall, A. Meyer, and D. H. Rose. - New York : Guilford Press, 2012. - 156 p.

21. Burgstahler Sh. Equal Access: Universal Design of Instruction [Електронний ресурс] / Sh. Burgstahler. - Режим доступу : http://www.washington.edu/doit/equal-access-universal-design-instruction. - Назва 3 екрана.

22. Keller J. M. Using the ARCS Motivational Process in Computer-Based Instruction and Distance Education [Електронний ресурс] / J. M. Keller // New Directions for Teaching and Learning. - 1999. $\begin{array}{llllll}\text { № } 78 . & - & \text { P. 39-47. } & - & \text { Режим } & \text { доступу }\end{array}$ http://www.qou.edu/arabic/researchProgram/distanceLearning/instructionDistance.pdf. - Назва $з$ екрана.

23. Гладких И. Б. Мотивация в дистанционном образовании (модель Келлера применимо к студентам с ОВ3) / И. Б. Гладких // Экономика и управление в XXI веке: тенденции развития. - 2015. - № 25. - C. 58-62.

24. Воронкін О. С. Організація діяльності тьютора в системі дистанційного навчання вищого навчального закладу / О. С. Воронкін // Інформаційні технології в освіті. - 2016. - № 1 (26). C. 177-191. 
25. Воронкін О. С. Мікроелектронні підсилювачі : електронний засіб навч. Призначення / О. С. Воронкін. - Луганськ : Вид-во СНУ ім. В. Даля, 2011. - 2 електрон. опт. диска (CD-ROM) ; 12 см. - Назва з контейнера.

26. Манюк Л. В. Структура й зміст електронного дистанційного курсу 3 англійської мови для студентів-медиків [Електронний ресурс] / Л. В. Манюк // Вісник Львівського державного університету безпеки життєдіяльності. - 2013. - № 7. - С. 275-280. - Режим доступу : http://nbuv.gov.ua/UJRN/Vldubzh_2013_7_44. - Назва з екрана.

27. MOODLE. Дистанционная поддержка обучения [Електронний ресурс]. - Режим доступу : https://www.herzen.spb.ru/img/files/dpo/moodle.pdf. - Назва з екрана.

28. Ascough R. S. Designing for online distance education: putting pedagogy before technology [Електронний ресурс] / R. S. Ascough // Teaching theology \& religion. - 2002. - Vol. 5. - № 1. - P. 17-29. - Режим доступу : http://post.queensu.ca/ rsa/2002_TTR_Ascough.pdf. - Назва з екрана.

29. Learning objectives: guidelines for writing effective learning objectives [Електронний ресурс]. - Режим доступу : http://www.park.edu/center-for-excellence-in-teaching-and-learning/resources/cetl-quicktips/learning-objectives.html. - Назва з екрана.

Матеріал надійшов до редакиї 06.01.2017 p.

\title{
ПЕДАГОГИЧЕСКАЯ СУЩНОСТЬ ПОНЯТИЯ «СЦЕНАРИЙ ДИСТАНЦИОННОГО КУРСА» (НА ПРИМЕРЕ АВТОРСКОГО ОПЫТА В ОБЛАСТИ ЭЛЕКТРОНИКИ)
}

\author{
Воронкин Алексей Сергеевич \\ преподаватель предметно-цикловой комиссии общеобразовательных и социально-экономических \\ дисциплин, специалист высшей категории, кандидат педагогических наук \\ КУ «Северодонецкое музыкальное училище имени С. С. Прокофьева», г. Северодонецк, Украина \\ alex.voronkin@gmail.com
}

\begin{abstract}
Аннотация. В статье представлены обобщенные подходы к толкованию понятия «сценарий дистанционного курса». Акцентировано внимание на мотивирующих факторах, которые тесно взаимосвязаны со средствами актуализации интереса; проблемными вопросами; организацией коллективного сотрудничества; спланированностью учебного процесса; методикой оценивания результатов деятельности; системой поощрений и др. Проанализирована разработка сценария на примере авторского дистанционного курса «Схемотехника», предназначенного для студентов высших учебных заведений, обучающихся по направлению «Микро- и наноэлектроника». Рассматривается структура разделов, предисловие, инструкции, план предлагаемой деятельности, цели обучения, организация работы в малых группах, рейтинговое оценивание деятельности слушателей, а также особенности проведения тематических форумов-дискуссий и рефлексия. Приведена универсальная план-схема по разработке сценария дистанционного курса.
\end{abstract}

Ключевые слова: высшее образование; дистанционный курс, сценарий; мотивирующие факторы.

\section{PEDAGOGICAL ISSUES OF THE CONCEPT «SCENARIO OF THE ONLINE COURSE» (BASED ON THE AUTHOR'S EXPERIENCE IN ELECTRONICS)}

\section{Oleksiy S. Voronkin}

Teacher of the subject cyclic commission for the general educational, social and economic sciences, specialist of the highest qualification, PhD in Pedagogic sciences

Communal institution «S. S. Prokofiev Severodonetsk Regional Music School», Severodonetsk, Ukraine alex.voronkin@gmail.com

\begin{abstract}
The article gives generalized methods for the interpretation of the concept ,online course scenario". Attention is emphasized on motivating factors that are closely allied with methods of actualization of the interest; problematic questions; technology and organization of
\end{abstract}


collaboration; planning of educational process; methodology of evaluation of the activity's results; system of encouragement, etc. As an example there were offered the scenario of author's online course "Circuit design" for students of universities and institutions who study "Micro- and nanoelectronics". The article considers the structure of chapters, foreword, instruction for the course, plan of suggested activity, aims of studies, organization of work in small groups, rating evaluation of the activity, and also features of conducting of theme forums and discussions and reflection. There was given the universal plan-scheme as for development of the online course scenario.

Keywords: higher education; online course; scenario; motivating factors.

\section{REFERENCES (TRANSLATED AND TRANSLITERATED)}

1. Maliukova I. G. ICT application in higher education of the of Ukraine [online] / I. G. Maliukova // ICTs in Higher Education in CIS and Baltic States: State-of-the-Art, Challenges and Prospects for Development : analytical survey. - St. Petersburg : GUAP, 2009. - P. 130-153. - Available from : http://iite.unesco.org/pics/publications/ru/files/3214561.pdf. (in Russian).

2. Kuz'minov Ja. I. As a matter of fact we face the revolution [online] / Ja. I. Kuz'minov // Website of the Higher School of Economics. - 2013. - Available from : http://www.hse.ru/news/105336334.html. (in Russian).

3. Bogachkov Yu. M. Project concept «distance learning of pupils» [online] / Yu. M. Bogachkov, V. Yu. Bykov, V. O. Krasnoshapka, V. M. Kukharenko, Yu. Ya. Pasikhov // Information Technologies and Learning Tools. $\quad-\quad 2009 . \quad-\quad$ № 5 (13). $\quad$ - $\quad$ Available from : http://journal.iitta.gov.ua/index.php/itlt/article/view/186/172. (in Ukrainian)

4. Maiboroda O. V. Distance education as a priority direction in post secondary education / O. V. Maiboroda // Information Technologies and Learning Tools. - 2011. - № 5 (25). - Available from : http://journal.iitta.gov.ua/index.php/itlt/article/view/452/440. (in Ukrainian)

5. Clark R. Accelerating expertise with scenario based learning [online] / R. Clark // Learning Blueprint. Merrifield, VA : American Society for Teaching and Development, 2009. - Jan. - P. 84-85. Available from : http://www.clarktraining.com/content/articles/ScenarioBasedLearning.pdf. (in English).

6. Savery J. R. Overview of Problem-based Learning: Definitions and Distinctions [online] / J. R. Savery // Interdisciplinary Journal of Problem-based Learning. - 2006. - № 1 (1). - P. 9-20. - Available from : http://docs.lib.purdue.edu/ijpbl/vol1/iss1/3. (in English).

7. Dikke D. Go-lab MOOC-an online course for teacher professional development in the field of inquirybased science education [online] / D. Dikke, N. Faltin. - Available from: http://www.go-labproject.eu/sites/default/files/files/publications/file/EDULEARN_MOOC_final.pdf. (in English).

8. Juracz L. Developing courses with holorena, a framework for scenario-and game based e-learning environments [online] / L. Juracz // International Journal of Software Engineering \& Applications (IJSEA). $\quad-\quad 2010 . \quad-\quad$ Vol. $1 . \quad-\quad$ № $4 . \quad$ - 4 Available from : https://arxiv.org/ftp/arxiv/papers/1011/1011.0350.pdf. (in English).

9. 7 Tips for Better E-Learning Scenarios [online]. - Available from : http://blogs.articulate.com/rapidelearning/7-tips-for-better-e-learning-scenarios. (in English).

10. Kushnir I. M. The structure of the distance course on Russian for foreign students of non-philological specialties [online] / I. M. Kushnir, I. V. Petrov, T. I. Kuriliuk // The teaching of languages in higher educational institutions today. Intersubject ties. Scientific research. Experience. Search. - 2013. - Vol. 23. - P. 43-53. - Available from : http://www-center.univer.kharkov.ua/vestnik/full/351.pdf. (in Ukrainian).

11. Build Branched E-Learning Scenarios in Three Simple Steps [online]. - Available from : http://blogs.articulate.com/rapid-elearning/build-branched-e-learning-scenarios-in-three-simple-steps. (in English).

12. Demkin V. P. Distance Learning Technologies / V. P. Demkin, G. V. Mozhaeva. - Tomsk : Tom. gos. un-t, 2003. - 106 p. (in Russian).

13. Novokreshhin B. G. Scenarios of learning [online] / B. G. Novokreshhin. - Available from : http://www.proshkolu.ru/contest/scenarii/blog/51090. (in Russian).

14. Rutkausk'ene D. E-learning technologies and resources / D. Rutkausk'ene, R. Kubiljunas, D. Gudoniene and etc. - Kharkov : Tochka, 2011. - 352 p. (in Russian).

15. The third university competition for the selection of pedagogical scenarios open online courses [online]. Available from : https://ido.tsu.ru/competitions/h_teachers-3/2015-16. (in Russian). 
16. Semash K. Competent e-course scenario [online] / K. Semash. - Available from : http://ycoach.ru/gramotnyj-scenarij-elektronnogo-kursa. - Назва з екрана. (in Russian).

17. E-learning scenario [online]. $\quad$ A $\quad$ Available https://www.crmm.ru/knowledge_base/Sozdanije_elektronnogo_kursa/Scenarij_elektronnogo_kursa. (in Russian).

18. Semenchenko R. D. Scenarios of learning in training simulators [online] / R. D. Semenchenko // Science and Modernity. - 2016. - № 44. - Available from : http://cyberleninka.ru/article/n/stsenarii-obucheniyav-obuchayuschih-trenazherah. (in Russian).

$\begin{array}{lllllll}\text { 19. CourseLab 2.7 } & \text { User } & \text { guide } & \text { [online]. } & - & \text { Available } & \text { from }\end{array}$ http://www.courselab.ru/courselab/WebHelp/indexh.htm. (in Russian).

20. Universal Design for Learning in the Classroom: Practical Applications / edited by T. E. Hall, A. Meyer, and D. H. Rose. - New York : Guilford Press, 2012. - 156 p. (in English).

21. Burgstahler Sh. Equal Access: Universal Design of Instruction [online] / Sh. Burgstahler. - Available from : http://www.washington.edu/doit/equal-access-universal-design-instruction. (in English).

22. Keller J. M. Using the ARCS Motivational Process in Computer-Based Instruction and Distance Education [online] / J. M. Keller // New Directions for Teaching and Learning. - 1999. - № 78. - P. 39_ $47 . \quad$ - $\quad$ Available from http://www.qou.edu/arabic/researchProgram/distanceLearning/instructionDistance.pdf. (in English).

23. Gladkih I. B. Motivation in Distance Education (Keller model applies to students with OVZ) / I. B. Gladkih // Economics and Management in the XXI century: trends. - 2015. - № 25. - P. 58-62. (in Russian).

24. Voronkin O.S. The organization of tutor's activity in the system of distance education at higher educational establishment / O. S. Voronkin // Information Technologies in Education. - 2016. - № 1 (26). - P. 177-191. (in Ukrainian).

25. Voronkin O. S. Microelectronic amplifiers: the e-tool for educational purposes / O. S. Voronkin. Lugansk : Vyd-vo SNU im. V. Dalia, 2011. - 2 CD-ROM ; 12 centimeter. - The name of the container. (in Ukrainian).

26. Manyuk L. V. The structure and content of electronic distance learning course in English for medical students [online]] / L. V. Manyuk // Journal of Lviv State University of Life Safety. - 2013. - № 7. P. 275-280. - Available from : http://nbuv.gov.ua/UJRN/Vldubzh_2013_7_44. (in Ukrainian).

27. MOODLE. Remote support of learning [online]. - Available from : https://www.herzen.spb.ru/img/files/dpo/moodle.pdf. (in Russian).

28. Ascough R. S. Designing for online distance education: putting pedagogy before technology [online] / R. S. Ascough // Teaching theology \& religion. - 2002. - Vol. 5. - № 1. - P. 17-29. - Available from : http://post.queensu.ca/ rsa/2002_TTR_Ascough.pdf. (in English).

29. Learning objectives: guidelines for writing effective learning objectives [online]. - Available from : http://www.park.edu/center-for-excellence-in-teaching-and-learning/resources/cetl-quick-tips/learningobjectives.html. (in English).

Conflict of interest. The author has declared no conflict of interest.

\section{(c) EY-NC-SA}

This work is licensed under Creative Commons Attribution-NonCommercial-ShareAlike 4.0 International License. 